\title{
THE DIFFERENCES BETWEEN HUMAN
R
RESOURCE MANAGEMENT IN DOMESTIC
总
AND INTERNATIONAL ENVIRONMENT
}

College of Applied Studies in Management and Business Communication,

Sremski Karlovci

Milijanka Ratković

Union - Nikola Tesla University, Faculty of Business Studies and Law, Belgrade

Dejan Dašić

Business College of Applied Studies, Academy of Business Economics, Čačak

\begin{abstract}
Today's business operation of a company goes beyond national boundaries while human resources are the only active resource of companies. Therefore, the topic of the actuality of human resources management in the domestic and international environment is becoming larger, which is also the starting point in the analysis of this issue. Considering the importance of human resources in business, this paper is concerned with the international human resource management, or the differences between human resource management in the domestic and international environment. The aim of this paper is to present international human resource management as a broader concept than national human resource management. Accordingly, the paper will show differences that come from human resources management in the national and international environment as well as some of the implications regarding the purpose and learning opportunities of companies that internationalize their business. The basic premise in this paper is that there are differences between human resource management in the domestic and international environment.
\end{abstract}

Key words: Human resource management, international environment, the internationalization of business, managers, employees

\section{Introduction}

With the internationalization of business operations, human resources management, which until then has only been used in a domestic environment, gets an international character. The main activities of human resource management, regardless of whether they are implemented in a company that operates solely on the 
domestic market or in the company that internationalizes its operations, should be directed toward achieving better performance of the company. Considering the fact that they are implemented in different settings, there are differences between domestic and international human resource management.

The starting point of this issue analysis is in the markets internationalization, or in globalization, resulting in the creation of an international character of human resource management. According to the starting point, the subject of this paper is human resources, both in international and in the domestic environment. The first part of the paper is concerned with internationalization of companies, which is in modern conditions dictated by globalization, considering that this is a necessary condition for the emergence of international human resource management. The second part, due to the diversity of literature and the existence of different approaches, is the definition of the international human resource management concept. The next section shows the factors that influence the differentiation of human resources management in the domestic and international environment, while the fourth part of this paper is about the differences in the activities, which are caused by the action of the international environment factors. The aim of this paper is to present the international human resource management as a wider concept in relation to the human resources management in the domestic environment. That is, to perceive, specify and explain the differences, and to carry out some of the implications, especially those concerning the purpose and learning opportunities of the companies which are internationalizing their business. According to the aim stated, the basic hypothesis is that there are differences between human resources management in domestic and international environment. This paper is a review based on relevant literature, and on professional and scientific works in the field of international human resource management.

\section{The Internationalization of Business and Human Resource Management}

The last decades of the 20th and beginning of the 21st century have been characterized by intensive processes of trade exchange, trans-boundary flow of capital, technology and people. These processes are often referred to as globalization, and its most important feature is to connect and establish interdependencies between different national economies.

Global international business strategy has become an inevitable option, not only for multinational and large companies, but also for medium and small companies that depend on global supply sources, whose products and services are designed for specific segments of the world market, which is facing global competition and the challenges in the global environment. ${ }^{1}$ Globalization is a complex process that can be viewed from different perspectives, primarily economic, political, social and cultural. Globalization can be considered as "the process of integration of markets, goods and capital around the world, which eliminates or reduces barriers to international trade and investment. Its

\footnotetext{
${ }^{1}$ Milenović Božidar, Ratković Milijanka: Marketing, Sremski Karlovci 2012, 32.
} 
The Differences Between Human Resource Management In Domestic And ...

roots are in the progress of technology, transport, in improvement of information flow, but also in changes of political and social character which reduce protectionism, liberalize rules for foreign investment and allow easier migration of the population."2

In the conditions of global economy, the company can no longer view national market as the only business and resources extraction environment for a successful business, but it must take into consideration a broader or regional, continental and global level. To be successful in such circumstances, the company should develop a completely different strategy than the one that is valid for the business within national markets, and human resource should be one of the key elements of this strategy. Competition as one of the main pillars of the market economy turns into global competition, not only in the field of quality of products or services and technology, but also in terms of enterprise management, and thus in terms of human resource management as a very important factor of business of each company.

The concept of Human Resources was first developed and popularized in the United States, where the management as a discipline comes from. According to this concept, the employees in the company are treated as one of the most important resources that a company has. Human resource management is regarded as a part of the management's sphere in the company, and is based on the theoretical and practical knowledge in the field of work psychology. Human resources management is becoming a separate discipline within the management that is focused on the study and management of employees in the company, who, with their own characteristics, knowledge, skills, abilities and overall mental and physical capacities, are one of the key success factors of the company. Therefore, the employees of the company are no longer viewed as a cost to be reduced, but as a potential source of competitive advantage, or as associates and partners in the realization of success.

Today, many authors point out that human resources are a central resource for survival, an engine for growth and competitive advantage. In addition, managers accept the fact that people, not money, buildings or equipment, are the key resource in the global market. Considering that since the beginning of the new millennium, it has been emphasized that the global economy is increasingly developing on the knowledge economy, people as holders of knowledge become an important lever for profit. All assets of a company, other than people, are considered as nothing more than a commodity that can be bought at market prices. In addition, all resources, except the people are considered as passive, because they require human interaction in order to create new value ${ }^{3}$. At the same time, it is emphasized that only human resources can learn, grow, and thus further contribute to the success of the company. ${ }^{4}$ If we accept that employees today, for the most part, are a precondition for the successful operation of the company, it appears that the main task for the company is to attract and retain the best people. Therefore, the quality performance of a wide range of activities and tasks related to human resources management gets vital importance.

Human capital is maximized through three key activities: persuading people to join a particular company, their retention and their development. Companies must define what kind of people they want and what kind of employees they need in the new business

\footnotetext{
${ }^{2}$ Adler S. Paul, Clark B. Kim: "Behind the Learning Curve: A Sketch of the Learning Process", Management Science 3/1991, 267-281.

${ }^{3}$ Beardwell lan, Holden Len, Claydon Tim: Human Resource Management, Essex 2004, 44.

${ }^{4}$ Bartlett A. Christopher, Ghoshal Sumantra: "Managing across Borders: The Transnational Solution", Journal of International Business Studies 1/2000, 101-120.
} 
environment posed by globalization. The companies must know how to find the people they need, how to attract and persuade people to work for them. In addition, companies must know how to keep people and how to gain their loyalty. In this way, the management of human resources will perform its primary function, that is to increase the intellectual and "intangible" capital of the company.

Human resources management directed towards training and motivating employees to more efficient fulfilment of the customers' needs and desires, and attraction of the right staff and maintenance of good long-term relationship with them is one of the basic prerequisites for survival in today's market. ${ }^{5}$ Human resource management today is becoming very important, if not crucial, link in the chain of business success for each company. For this reason, in recent years in the economic, managerial, accounting and psychological literature is increasingly discussing how the failure of companies in the field of human resources can have adverse effects on the overall operations of the company.

\section{Basic Characteristics of International Human Resource Management}

The term Human Resources refers to the totality of human resources in the enterprise: knowledge, abilities, skills, creativity, motivation, energy, etc., which are necessary for the achievement of company goals. Human resource management can be defined as a management activity that involves providing, developing, maintaining, adapting, directing and using of Human Resources, in accordance with the objectives of the company while respecting the individual needs and goals of employees. In an international environment, posed by globalization, it comes to the changed role and content of Human Resources management in companies, so that in this respect we can speak of international human resource management as a separate discipline.

International human resource management is defined as a set of specific activities, functions and processes that are undertaken to attract, develop and retain human resources in a company whose business has a multinational character. ${ }^{6}$ This definition suggests that the main factor that differentiate domestic from international human resources management is the character of the environment in which the company operates. Companies that are centered exclusively on the domestic market do not face the international environment as the environment in which they operate their business. The environment in which they operate can be defined as a national business system, and it is made from a set of relationships between government, capital and labour and beside the economic, it has political-institutional and legal character too.

Almost every country has its own peculiarities in terms of organizing the relations between capital and labour, which significantly influence the business strategy of the company. Comparative human resources management appears in this sense as a discipline that is of great importance for the international human resources management,

\footnotetext{
${ }^{5}$ Ratkovic Milijanka: „Interni marketing u funkciji povećanja zadovoljstva kupaca“, Marketing 4/2009, $269-275$.

${ }^{6}$ Brewster Chris, Sparrow Paul, Vernon Guy: International Human Resource Management, London 2007, 960.
} 
The Differences Between Human Resource Management In Domestic And ...

as it is the study of similarities and differences between the various states regarding practice in the field of human resources $(5$, p.44). However, there are reflections of some authors that the practice of human resource management should not vary significantly from state to state, because the human resource management in every company, regardless of the country where it operates, has the same goal, which is to optimize the performance of the company. ${ }^{7}$

The main task of the international human resource management refers to how to solve the multi-dimensional puzzle consisting of different national and organizational cultures ${ }^{8}$. Thereby, as shown in Figure 1, three dimensions of the problem should be kept in mind:

1. The question of acquisition, allocation and utilization of human resources, i.e. planning, selection, socialization, training and development, modes of compensation, performance evaluation, and so on in international human resource management;

2. The reconciliation between the three categories of countries involved in international human resource management - the host country, where one of the parts of the company is; home country where the headquarters is, and a third state, which can be a source of manpower or financial resources;

3. Three types of employee treatment - employees who are citizens of the host country, employees who are citizens of the home country and the employees who are citizens of some third country or countries. ${ }^{9}$

\section{Human resource activtties}

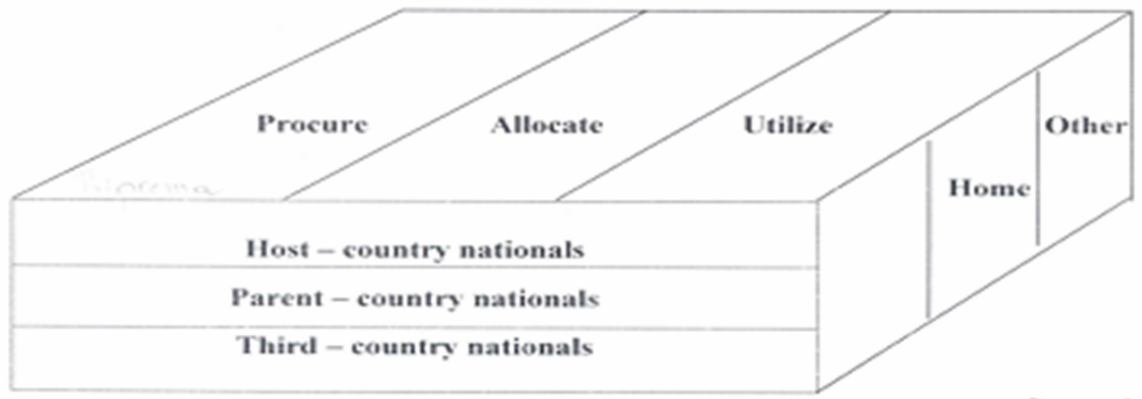

Countries

Type of employees

Figure 1 - Morgan's model of international human resource management

(Source: Morgan V. Paul: "International Human Resource Management: Fact or Fiction", Personnel Administrator, 9/1986, 44.)

\footnotetext{
${ }^{7}$ Ibid, 65 .

${ }^{8}$ Laurent Andre: "The Cross-cultural Puzzle of International Human Resource Management", Human Resource Management 1/1986, 91-102.

${ }^{9}$ Morgan V. Paul: "International Human Resource Management: Fact or Fiction", Personnel Administrator 9/1986, 43-47.
} 
Companies sometimes overlook the complexity of international business operations and often do not pay enough attention to these three dimensions. Therefore, the reason of failure in international business can be very often found in poor human resource management. Strategic human resources management needs to align with strategic needs of the organization and to employ effectively human resources. However, for a strategic approach to human resource management in an international environment it is essential to invest in human resources, since a significant proportion of human capital is determined by the knowledge and skills that individuals acquire. Personal knowledge and skills greatly affect the performance of employees, and the task of human resource management should be to encourage employees for training, attending courses and other forms of professional upgrading in order to be prepared to cope with the challenges posed by international operations. Therefore, education of employees is a very important factor in the success of companies in international business. In addition, given that, creativity and innovation are playing a growing role in gaining competitive advantage in international business, human resource management should contribute to the creativity of employees, and tactics for innovations developing should enable the implementation of new ideas.

\section{Factors Influencing the Differentiation Between Human Resource Management in Domestic and International Environment}

Specificity of human resources management in international compared to domestic environment largely stem from the necessity of operating in different countries and the necessity of employment the citizens of the home state and citizens of foreign countries. Therefore, human resources management in the company that internationalizes its operations must take into account the type of foreign countries where its business is expanded. Thereby, the key institutional differences between countries include differences in political, legal, economic and business systems. ${ }^{10}$ Different countries have different systems of political order, legal, economic and business system from which they derive specific tasks faced by human resource management. Companies that want to operate globally regard the whole world as a source from which they can be supplied with resources necessary for their operations, and will endeavour to carry out their business activities around the world, apply global business strategy and go beyond the external borders of the business. The key questions in such circumstances are related to:

- Employment opportunities for workers who come from countries where the office of the company in a foreign country is;

- The conditions for engagement of workers who are citizens of the host country and the workers who are citizens of third countries;

- Establishment of a employment form;

- The problems arising due to the differences in the tax system and regulations are related to the regulation of the labour, health and social security and insurance of employees.

\footnotetext{
${ }^{10}$ Sparrow Paul, Brewster Chris, Harris Hilary: Globalizing Human Resource Management, London 2004, 123.
} 
The Differences Between Human Resource Management In Domestic And ...

Human resources management in terms of international business must pay special attention to the study and development characteristics of the economic system of a country, as well as the characteristics of the national business systems of foreign countries. Different countries are at different stages of economic development, they have different economic systems, from those who operate on a market basis, to those in which the government, more or less does interventions and creates economic sphere. Conditions of employment and payment of employees vary from state to state, and they are generally labelled by each economic and business system. In some developed countries, the labour force is expensive and there prevails higher level of average income per capita, and the underdeveloped countries are characterized by cheap labour force and low level of average per capita income. In addition, human resource management in an international environment must solve numerous problems related to the payment of different types of compensation for employees of different nationalities. Therefore, some authors believe that international human resource management should use different approaches in different countries in terms of the system of payment and compensation of employees."

Complexity of business operations in different countries, hiring and paying people from different nationalities, distinguishing the activities of management in the domestic and international environment, in addition to the before mentioned, are influenced by several other factors. As indicated in Figure 2. the most significant factors among them are:

- Cultural environment;

- Industry (or industries) in which the company is primarily involved;

- Senior managers' attitudes;

- Company dependence from domestic market. ${ }^{12}$

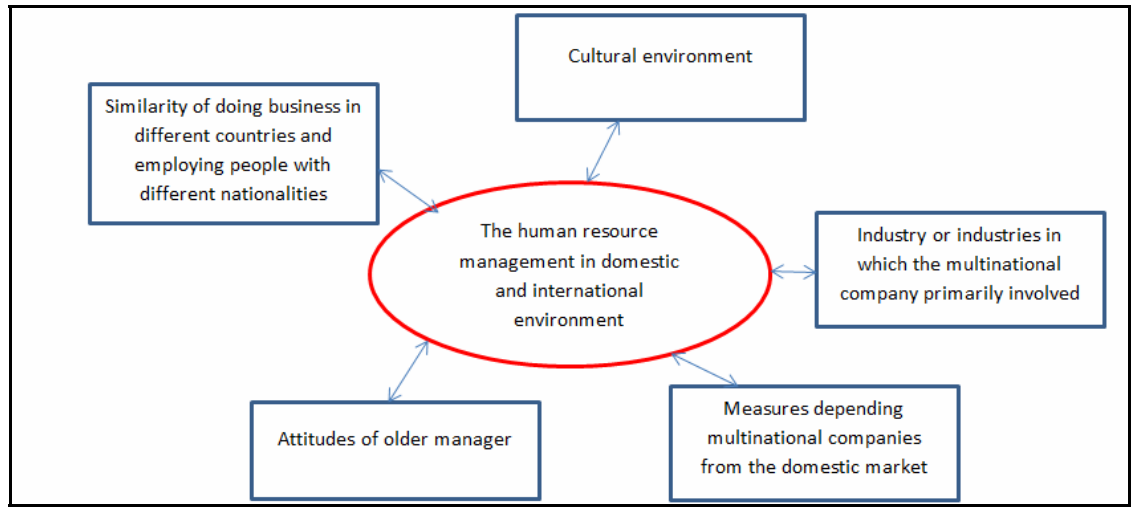

Figure 2 - Factors affecting the differences between the human resources management in the domestic and international environment

(Source: Dowling J. Peter, Festing Mario, Engle D. Allen: International Human Resource Management: Managing People in a Multinational Context, London 2008, 9.)

${ }^{11}$ Ding Daniel, Fields Dail, Akhtar Syed: "An Empirical Study of HRM Policies and Practices in Foreigninvested Enterprises in China: The Case of Shenzhen Special Economic Zone", International Journal of Human Resource Management 5/1997, 595-613

${ }^{12}$ Dowling J. Peter, Festing Mario, Engle D. Allen: International Human Resource Management: Managing People in a Multinational Context, London 2008, 9. 


\section{Cultural Environment}

Culture can be defined as a set of beliefs, values and ways of life that is common to a particular group of people, and which significantly shapes the way of thinking, feelings and reactions of members of the particular human group ${ }^{13}$. It often predetermines behaviour patterns, attitudes, standards, and the value of a wider community. In the international management, the individual authors define culture as the collective programming of the mind that is different from a single person to person, depending on their belonging to different social groups and nations.

In a global economy, cultural environment is a very important factor. The ability to achieve success in international business depends not only on the knowledge of the economies and qualities of different countries, but also on knowledge of other countries' culture, the differences among cultures, and the knowledge of dominant organizational culture in companies of some country. To prove that culture is important for economic development, it is first necessary to show that culture has potentially important aspects that differ between countries, and second, that these aspects of culture significantly affect the economic results ${ }^{15}$. We should bear in mind that even within a country we could mark differences in culture between different parts of a territorial state, ethnic groups and various companies. Therefore international human resource management must be interested, not only for identifying cultural differences, but also for developing cultural intelligence and international cultural competence of employees who perform their activity in the international environment. ${ }^{16}$

Differences in culture are reflected in the diversity of language, communication rules, the interpretation of procedures, business practices, attitudes towards work and time, eating habits and hygiene. That is why people of different nationalities have different attitudes, behaviours and beliefs, and the activities of human resource management must pay attention to the cultural environment in hiring, training, remuneration, promotion and dismissal of workers. Special attention of human resources management in an international environment requires the relocation of workers on a job that involves working in different cultural environments.

Cultural environment directly defines organizational culture, why it is of great importance to understand this factor in the international environment. Organizational culture is the most powerful tool for understanding human behaviour in organizations. ${ }^{17}$ Therefore, in order to understand the behaviour of employees it is necessary to be familiar with the impact of cultural factors in the market in which we operate, and in accordance with this we should try to create the appropriate relationships in order to improve the overall business.

\footnotetext{
${ }^{13}$ Laroche Lionel, Rutherford Don: Recruiting, Retaining, and Promoting Culturally Different Employees, Burlington 2007, 2.

${ }^{14}$ Helms M. Michael: Encyclopedia of Management, Farmington Hills 2006, 385.

${ }^{15}$ Obradović Saša, Rakić Biljana, Šapić Srđan: „Kulturološke razlike kao faktor ekonomskog uspeha“, Ekonomske teme 4/2011, 619-632.

${ }^{16}$ Helms M. Michael: Encyclopedia of Management, Farmington Hills 2006, 385.

17 Janićijević Nebojša: „Uticaj organizacione kulture na liderstvo u organizaciji“, Ekonomske teme 4/2011, 527-543.
} 
The Differences Between Human Resource Management In Domestic And ...

\section{Industry (or industries) in which the company is primarily involved}

Every industry in globalization conditions is characterized by a certain degree of pressure that creates competition, so the strategy of each company, which is involved in international business, must consider this fact. In addition, the competitive position of a company in the domestic market is also reflected in the competition at the international level. Global industry is not just a collection of local industries, but compound-related domestic industries where competitors compete against one another on international basis $^{18}$. As there are large industries, for whose operations there are no national boundaries and differences in economic structures, there are also domestic industries that are significantly associated with the same type of industry in other countries.

The role of human resource management in local industries connected with the same type of industry in other countries, and global industries as well can be analyzed using a model of the value chain, according to which human resources management is one of the support pillars for business enterprises, as human resource management permeates the entire value chain of enterprises. ${ }^{19}$ If the company operates in the domestic industry, which is significantly associated with the same type of industry in other countries, human resources management will then operate mainly as it does in the domestic environment. In case that there is a need for occasional international business, the company will hire consulting firms or temporary workers specialized in this area. It is a different situation when the company is included in the global industry, in which the management of human resources should be structured in a manner dictated by international business.

\section{Attitudes of senior managers toward international business}

If senior managers in the company have no extensive experience in international business, some significant operations of an international character can be ignored, even when it regards to those that are related to the achievement of some of the major corporate goals and objectives ${ }^{20}$. In regards to human resource management, their attitude often consist of the fact that the existing practice in the field of human resources realized in company's business in the domestic environment, should only be transferred to the international business. Inability to recognize the differences between doing business in domestic and international conditions and the diversity of human resource management activities in the domestic and international environment can be a source of failure for the company. Therefore, the challenge for the human resources management is to think globally and to prepare human resources for the implementation of the policies and practices of international business operations. ${ }^{21}$

\footnotetext{
${ }^{18}$ Sparrow Paul, Brewster Chris, Harris Hilary: Globalizing Human Resource Management, London 2004, 40.

${ }^{19}$ Dowling J. Peter, Festing Mario, Engle D. Allen: International Human Resource Management: Managing People in a Multinational Context, London 2008, 13.

${ }^{20}$ Bartlett A. Christopher, Ghoshal Sumantra: "Managing across Borders: The Transnational Solution", Journal of International Business Studies 1/2000, 101-120.

${ }^{21}$ Dowling J. Peter, Festing Mario, Engle D. Allen: International Human Resource Management: Managing People in a Multinational Context, London 2008, 17.
} 


\section{Company dependence on domestic market}

Human resource management must pay special attention to how much the company's operations depend on the domestic market. As a rule, for large companies, the domestic market is narrow for the realization of planned business activities, and so they have to internationalize their business. And vice versa, small businesses are often assumed to realize their business activities within the domestic market. However, the size of the company is not decisive in regards to the internationalization of business, because even for large companies domestic market is very important. ${ }^{22}$ United Nations Conference on Trade and Development (UNCTAD), which is published annually in its research about foreign direct investment, calculates the transnationality index of companies, which represents an average coefficient of:

- Foreign assets in relation to total assets;

- Overseas sales to total sales;

- Employment abroad to total employment. ${ }^{23}$

This index or other similar indicators can be of great assistance to human resource management in an international environment in terms of planning their activities.

\section{The Differences in Activities Between Human Resources Management in the Domestic and International Environment}

In order to be competitive in the global market, companies are pressed by the need to simultaneously and equally efficient manage at two levels:

- Globally, since the whole world is a unique market for them and that the only globally integrated strategy provides the company with a competitive advantage in the global market

- Locally, considering the importance of the domestic market for most businesses, regardless of whether they mainly operate in the domestic or international environment.

The need that the companies should be both global and local is the biggest challenge for human resource management ${ }^{24}$. As more and more companies operate in an international level, the search for elements of global competitive advantage is a major topic in the literature about management ${ }^{25}$, and in particular, it relates to the field of international human resource management. ${ }^{26}$

\footnotetext{
${ }^{22}$ Ibid, 14

${ }^{23} \mathrm{Ibid}, 14$.
}

${ }^{24}$ Schuler S. Randall, Budhwar S. Pawan, Flakowski G. Paul: "International Human Resource Management: Review and Critique", International Journal of Management Reviews 1/2002, 41-70.

${ }^{25}$ Dickmann Michael, Muller-Camen Michael: „A Typology of International Human Resource Management Strategies and Processes“, International Journal of Human Resource Management 4/2006, 580-601.

${ }^{26}$ Schuler S. Randall, Dowling J. Peter, De Cieri Helen: "An Integrative Framework of Strategic Human Resource Management", Journal of Management 2/1993, 419-459. 
The Differences Between Human Resource Management In Domestic And ...

Effective human resource management in an international environment is seen as a key source of competitive advantage in international business. Due to the importance of this topic, there has been a significant intensification of research in the framework of international human resource management in the last few years. Some of the most important debates are about development of models and concepts of strategic international human resource management, and about the question if successful domestic strategy of human resource management can be applied in international business enterprises ${ }^{27}$. Although it was taught before that, there is no difference between a good human resource management in the domestic and international environment, some recent research suggests otherwise. International human resource management has many similarities with the local management of human resources. They coincide in all the basic functions. ${ }^{28}$

However, there are several very important differences between the human resource management in domestic and international environment. Although international human resource management has the same functions as human resources management in the domestic environment, it also has many additional functions arising from the broader perspective that it covers. More and more companies tend to internationalize their business, and as a result, human resources management has to fulfil requirements concerning the problems of the company in an international environment ${ }^{29}$. In doing so, companies are often faced with the problem that arises from the inability to apply the best practices in human resource management in the domestic environment on its own international business. As some of the possible reasons of this problem, most often are mentioned: ${ }^{30}$

- More activities in human resource management in an international environment;

- Broader perspective of human resource management in an international environment

- The need for greater involvement of the private lives of employees in international human resources management;

- Various combinations of employees: citizens of the home country, host country and third countries in international human resource management;

- Greater risk in carrying out all the activities of international human resource management;

- Strong influences exposure of external factors in international human resource management.

\section{Additional activities of human resource management in an international environment}

In order for a company to function freely in the international environment, human resource management has to take on more activities than when the company operates only in the domestic market. Among the additional activities of human resource management, the most important tasks are: in the framework of international tax systems,

\footnotetext{
${ }^{27}$ Schuler S. Randall, Jackson E. Susan: Strategic Human Resource Management, London 2007, 162.

${ }^{28}$ Leopold John, Harris Lynette, Watson Tony: The Strategic Managing of Human Resource, New Jersey 2004, 270.

${ }^{29}$ Briscoe R. Dennis, Schuler S. Randall: "The future of HR: The critical issues", Management 82004, 22-26.

${ }^{30}$ Dowling J. Peter, Festing Mario, Engle D. Allen: International Human Resource Management: Managing People in a Multinational Context, London 2008, 5.
} 
organizing international relocation and orientation of individual employees, the establishment of administrative services for workers abroad, establishment of good relations with the government of the host country and the provision of translation services. ${ }^{31}$ These activities are the condition to establish good long-term relationships with employees, because only such relations can improve the overall operations of the company, both in the domestic and global environment. Establishing appropriate interaction or successful cooperation with employees should be the common goal of all market participants who wish to achieve and maintain a competitive position in contemporary business conditions ${ }^{32}$. It can be said that the establishment of good relations with one's employees in today's global business environment is one of the most significant activities of the company's management. In this respect, it is important to take all measures known to improve relations with employees abroad, but also to make additional efforts for exploring the market of the host country, and in accordance with their legal, political and other conditions define relationships, responsibilities, and potential achievements of employees. "The workers abroad are subject to foreign, and domestic taxation, and international human resource management must be familiar with all the differences in tax laws and procedures of their own and foreign country or countries, so the business activities of the company could easily take place. Activities within the international relocation and orientation of employees include preparation before immediate going abroad, providing details on immigration and travel, housing provision, health care, recreation, education, and consultation about compensation, such as sending salaries abroad, determination of various fees and tax treatment measures. ${ }^{33}$ "The company operating abroad must provide numerous administrative services for employees working abroad. These services are primarily related to the complexity of certain procedures in some countries, incompleteness and vagueness of existing regulations and procedures. By meeting these requirements, a potential conflict with the state in which the employee works is avoided. The establishment of good relations with the government of the host country should be very important activity of the international human resource management. There are a number of problems that can be assumed, but can occur and are unexpected, so that in such situations the assistance of the host country is greatly needed, therefore establishing a good relationship should be one of the priorities of human resource management.

\section{A Wider perspective of Human Resource Management in an international environment}

Human resource management in a company that operates in the domestic environment usually creates and implements programs for employees who are of one nationality, so that they all are covered with identical policy. International human

\footnotetext{
${ }^{31}$ Dowling J. Peter, Festing Mario, Engle D. Allen: International Human Resource Management: Managing People in a Multinational Context, London 2008, 5.

${ }^{32}$ Ratković C. Milijanka, Krasulja Nevena, Garača Neven: „Customer relationship management strategy as an opportunity for improving the modern marketing concept“, Kultura 139/2013, 381-395.

${ }^{33}$ Dowling J. Peter, Festing Mario, Engle D. Allen: International Human Resource Management: Managing People in a Multinational Context, London 2008, 5-6.
} 
The Differences Between Human Resource Management In Domestic And ...

resource management is faced with the problem of how to create and implement programs for employees who are members of different nationalities, which indicates the need for a much broader approach to the issue. Otherwise, one group of employees will feel undervalued in relation to the other, which will be a source its dissatisfaction.

\section{The necessity for greater involvement in the employees' private lives in international Human Resource Management}

In the international human resources management, there is much greater involvement in the employees' private lives due to the necessity of better selection, training and management in circumstances where, beside the mother country citizen, the citizens of the host country, also the citizens of third country or countries are employed. At the same time, "in an environment of modern marketing, the relationships with employees become one of the most important ways to influence on the maintenance of product quality ${ }^{34}$, and a need to develop a good relationship with them is seen as a priority of human resource management. This is particularly evident in regards to employees abroad. There must be certainty whether the employees who were sent to work abroad:

- Have a good understanding of all the requirements and procedures about work performance in a foreign country;

- Whether there are good health care provided by the host country;

- Whether their compensations are sufficient to cover the cost of living;

- Whether there are adequate educational facilities available for children's education.

In addition, many companies that operate internationally have a separate office for international human resources to coordinate all activities necessary for employed abroad. They also provide services such as managing the employees' bank accounts, investments and rental of property while they are engaged in work abroad, coordination of visits to the motherland and coordination of the procedure of employee's final return to homeland. ${ }^{35}$

\section{Different combinations of employees: citizens of the home country, host country and third country in International Human Resource management}

As the operation of a company abroad becomes more comprehensive and more serious, it will require changes in the human resource management and its activities. As the availability of quality human resources in the host country through the offer of quality

\footnotetext{
${ }^{34}$ Ratković C. Milijanka, Krasulja Nevena, Garača Neven: „Customer relationship management strategy as an opportunity for improving the modern marketing concept“, Kultura 139/2013, 381-395.

${ }^{35}$ Dowling J. Peter, Festing Mario, Engle D. Allen: International Human Resource Management: Managing People in a Multinational Context, London 2008, 7.
} 
workers who are citizens of the host country is getting bigger, so the need for hiring employees from the state or from third countries will reduce. Then the focus of human resource management, which was aimed at helping to the mother country citizens who are employed abroad, moves to the selection activities of the local labour, education and the management of its development. Later, the focus of activities is changing and the goal is to bring local labour force of high potential that would help the development of certain tasks. As the representative offices of the companies abroad are getting stronger, so the need to expand the responsibilities of local service of human resources and its activities, such as human resource planning, recruitment, training, development and compensation will become more present. ${ }^{36}$

\section{Higher risk in the performance of all activities of the international human resource management}

The consequences of failure in international operations of the company can be more dangerous than the consequences of a possible failure in business on the domestic market, what is the fact which human resource management must bear in mind. The failure and lack of effectiveness in the workplace abroad can cause more costs for the company. Direct costs of failure, such as salaries, training costs, and travel and relocation expenses may be for the company higher up to three times than domestic revenues. There we should add the cost of transfer depending on the difference in exchange rates and the place where the employee performs the task. The potential loss of foreign markets, and the opportunity to spoil relations with the host country are of particular importance. In addition, great risks for modern business are political instability in some parts of the world, the threat of terrorist attacks and the spread of infectious diseases. Therefore, international human resource management must pay attention to these risks and be prepared if necessary to organize the evacuation of employees.

\section{Exposure to stronger influence of external factors in the international human resource management}

The main external factor affecting human resource management in an international environment are different types of government, the diversity of economic conditions in different national markets and the existence of different procedures in business, in each of the countries in which the company that internationalized its activity operates. In developed countries, labour force is more expensive and better organized than the one that exists in developing countries, a government requires fulfilment of many conditions in terms of relationships with employees, paying taxes, health care and security. Human resource management in an international environment therefore has to study and interpret the local way of doing business. ${ }^{37}$

\footnotetext{
${ }^{36}$ Ibid, 7.

${ }^{37}$ Ibid, 8.
} 
The Differences Between Human Resource Management In Domestic And ...

\section{Concluding Remarks}

All of the above mentioned suggests that international human resources management, as compared to human resources management in the domestic environment, has far more complex work in order to achieve the most important objectives of human resource management in general. These objectives are related to securing efficiency and competitive advantage of the company that has internationalized its business.

International human resource management must come to grips with the issues that arise under the influence of cultural differences, differences in the business environment, a variety of policies, legal norms and procedures, different customs and traditions, foreign languages between two or more states. Even in the countries with small markets and market economies that do not play great importance in the world economy, the role of international human resource management is growing, because for successful companies domestic market becomes narrow, so they tend to expand their business to other countries. In addition, international human resource management, in accordance with wider context in which international business is performed, has more activities, takes place in a wider perspective than human resources management in the domestic environment. It is more involved in the private lives of employees, it must take into account the changes in the number of employees who are citizens of the home and the host country, it operates with a higher risk and is exposed to the stronger influence of external factors.

Considering all differences, it seems that human resource management in an international environment should seriously consider the question of organizational learning of the company. In the case of an international human resources management organizational learning is aimed at gaining knowledge about other nations, political, legal and economic systems, markets, customs, cultures, rules of communication. Understanding and appreciation of them must represent an imperative, given the propensity of certain cultures to impose their rules on others. The learning within the company operating in an international environment, based on the characteristics of the environment, is crucial according to some authors for growth and development of the company $^{38}$. Organizational learning is the process through which managers want to encourage the desire and ability of employees to mutual understanding. This understanding should contribute to "localizing the company", ${ }^{39}$ and therefore to more efficient managing the company and its environment. It is manifested either through changes in organizational knowledge, ${ }^{40}$ or through changes in organizational performance. ${ }^{41}$ However, despite the importance of organizational learning for companies that operate internationally, this topic is not elaborated enough in the

\footnotetext{
${ }^{38}$ Pucik Von: "Strategic Alliances, Organizational Learning and Comparative Advantage: the HRM Agenda", Human Resource Management 1/1988, 77-93.

${ }^{39}$ Senge M. Peter: The Fifth Discipline: The Art and Practice of the Learning Organization, London 1990, 287.

${ }^{40}$ Gruenfeld H. Deborah, Martorana V. Paul, Fan T. Elliott: "What Do Groups Learn from their Worldliest Members? Direct and Indirect Influence in Dynamic Teams", Organisational Behavior and Human Decision Processes 1/2000, 60-74.

${ }^{41}$ Adler S. Paul, Clark B. Kim: "Behind the Learning Curve: A Sketch of the Learning Process", Management Science 3/1991, 267-281.
} 
literature about international human resource management, and there is a gap in terms of recommendations how to develop this organizational ability, how to improve and how to ensure that this process will last continually. In this regard, the question is how companies that operate around the world, in dozens of countries, when facing with local specificities of each country can learn about the characteristics of these countries and the people who inhabit them. In addition, another question that needs answer is whether and how knowledge of other countries where the company operates can be used on the entire company in order to improve its overall organizational and business performance.

\section{Literature}

[1] Adler S. Paul, Clark B. Kim (1991): "Behind the Learning Curve: A Sketch of the Learning Process", Management Science 3/1991, 267-281.

[2] Bartlett A. Christopher, Ghoshal Sumantra (2000): "Managing across Borders: The Transnational Solution", Journal of International Business Studies 1/2000, 101-120.

[3] Beardwell lan, Holden Len, Claydon Tim (2004): Human Resource Management, Essex.

[4] Brewster Chris, Sparrow Paul, Vernon Guy (2007): International Human Resource Management, London.

[5] Briscoe R. Dennis, Schuler S. Randall (2004): "The future of HR: The critical issues", Management 8/2004, 22-26.

[6] Dickmann Michael, Muller-Camen Michael (2006): „A Typology of International Human Resource Management Strategies and Processes“, International Journal of Human Resource Management 4/2006, 580-601.

[7] Ding Daniel, Fields Dail, Akhtar Syed (1997): "An Empirical Study of HRM Policies and Practices in Foreign-invested Enterprises in China: The Case of Shenzen Special Economic Zone", International Journal of Human Resource Management 5/1997, 595-613.

[8] Dowling J. Peter, Festing Mario, Engle D. Allen (2008): International Human Resource Management: Managing People in a Multinational Context, London.

[9] Gruenfeld H. Deborah, Martorana V. Paul, Fan T. Elliott (2000): "What Do Groups Learn from their Worldliest Members? Direct and Indirect Influence in Dynamic Teams", Organisational Behavior and Human Decision Processes 1/2000, 60-74.

[10] Helms M. Michael (2006): Encyclopedia of Management, Farmington Hills.

[11] Janićijević Nebojša (2011): „Uticaj organizacione kulture na liderstvo u organizaciji“, Ekonomske teme 4/2011, 527-543.

[12] Laroche Lionel, Rutherford Don (2007): Recruiting, Retaining, and Promoting Culturally Different Employees, Burlington.

[13] Laurent Andre (1986): "The Cross-cultural Puzzle of International Human Resource Management", Human Resource Management 1/1986, 91-102.

[14] Leopold John, Harris Lynette, Watson Tony (2004): The Strategic Managing of Human Resource, New Jersey.

[15] Milenović Božidar, Ratković Milijanka (2012): Marketing, Sremski Karlovci.

[16] Morgan V. Paul: "International Human Resource Management: Fact or Fiction", Personnel Administrator 9/1986, 43-47.

[17] Obradović Saša, Rakić Biljana, Šapić Srđan (2011): „Kulturološke razlike kao faktor ekonomskog uspeha", Ekonomske teme 4/2011, 619-632. 
The Differences Between Human Resource Management In Domestic And ...

[18] Pucik Von (1988): "Strategic Alliances, Organizational Learning and Comparative Advantage: the HRM Agenda", Human Resource Management 1/1988, 77-93.

[19] Ratković C. Milijanka, Krasulja Nevena, Garača Neven (2013): „Customer relationship management strategy as an opportunity for improving the modern marketing concept", Kultura 139/2013, 381-395.

[20] Ratković C. Milijanka (2009): „Interni marketing u funkciji povećanja zadovoljstva kupaca“, Marketing 4/2009, 269-275.

[21] Schuler S. Randall, Budhwar S. Pawan, Flakowski G. Paul (2002): "International Human Resource Management: Review and Critique", International Journal of Management Reviews 1/2002, 41-70.

[22] Schuler S. Randall, Dowling J. Peter, De Cieri Helen (1993): "An Integrative Framework of Strategic Human Resource Management", Journal of Management 2/1993, 419-459.

[23] Schuler S. Randall, Jackson E. Susan (2007): Strategic Human Resource Management, London.

[24] Senge M. Peter (1990): The Fifth Discipline: The Art and Practice of the Learning Organization, London.

[25] Sparrow Paul, Brewster Chris, Harris Hilary (2004): Globalizing Human Resource Management, London. 